Abstracts of the ' Communications, Pacific Coast Branch.

Fourth meeting.

San Francisco, California, October 9, I9r3.

$$
23(840)
$$

Skin reaction in streptothrix infections.

By Edith J. Claypole (by invitation).

[From the Hearst Laboratory of Pathology and Bacteriology, University of California.]

There are a number of cases of obscure infection, especially of the lungs, which pass frequently as tuberculosis, clinically showing many similar symptoms, without, however, tubercle bacilli. Quite a proportion of these cases are due to a streptothrix infection. Detection by sputum examination is not nearly so easy or so definite as in tuberculosis, and after working over the subject in a variety of ways it seemed possible that a skin test similar to that made by old tuberculin might help in the problem. From two species of these organisms, S. eppingeri, a partly acidfast type, and S. hominis (III, Foulerton), a preparation was made exactly analogous to Koch's old tuberculin (a glycerine bouillon filtrate concentrated to $\mathrm{I} / \mathrm{roth}$ its original volume, making a 50 per cent. glycerin extract). The organisms were grown $4-6$ weeks at $37^{\circ} \mathrm{C}$. in 5 per cent. glycerine bouillon.

After making three slight abrasions of the skin on the upper arm with a von Pirquet chisel, the three preparations were gently rubbed in, leaving them to dry for Io minutes. The tuberculin was used as a control in each case, and the streptotricin preparations compared with it.

Eleven cases of tuberculosis, six non-tuberculous lung infections, and five infants from $3 \frac{1}{2}$ to 17 months were tested with the following results:

\begin{tabular}{c|c|c|c}
\hline \hline II Tuberculous........... & $\begin{array}{c}\text { Old Tuberculin } \\
\text { Streptotricin } \\
\text { Old Tuberculin } \\
\text { Streptotricin } \\
\text { Old Tuberculin } \\
\text { Streptotricin }\end{array}$ & $\begin{array}{l}\text { Positive 8 } \\
\text { Positive I } \\
\text { Positive I } \\
\text { Positive 6 } \\
\text { Positive I } \\
\text { Positive o }\end{array}$ & $\begin{array}{l}\text { Negative 3 } \\
\text { Negative ro } \\
\text { Negative 5 } \\
\text { Negative 0 } \\
\text { Negative 4 4 } \\
\text { Negative 5 5 }\end{array}$ \\
\hline
\end{tabular}


Streptothrix organisms in the form of the typical pinheadsized granules were found in the sputum of all six cases reacting to streptotricin. Two cases showed a positive reaction to both tests, and in the sputum of one, both organisms were present in profusion; in the other, only the streptothrix. All these cases reacting to the streptotricin show the characteristic organism in good sputum specimens.

The reaction in the cases so far observed is a bright red hyperemic area from 7-10 $\mathrm{mm}$. in diameter, a slight induration in the center, but without any tendency to form the dense induration of some of the tuberculin reactions. Examinations were recorded 24 and 36 to 48 hours after vaccination, but later in some cases where there was quite a tendency to induration, lasting even a week. Observations are now being made on other cases and on presumably normal people to determine the range and reliability of the reaction.

\section{$24(84 \mathrm{I})$}

Further note on the influence of cholesterol on the growth of tumors.

By Theo. C. BurnetT (by invitation).

[From the Rudolph Spreckels Physiological Laboratory of the University of California.]

In previous papers it has been shown by Robertson and the writer, that cholesterol accelerates the growth of carcinoma in rats, and also, in view of the recent work of Wacker and of Ellis and Gardner, it may be a factor in the incidence of cancer. ${ }^{1}$ In our original experiments the cholesterol was injected into, or around the tumor, and the criticism has been made, and justly too, we think, that the increase in the growth of the tumor might be due to the mechanical irritation of the injections, although we had previously controlled this possibility by injections of a balanced salt solution. We determined to test this matter further by making the injections on the opposite side of the body to that of the inoculations, and it has been the privilege of the writer to carry on these experiments in the absence of Robertson on sab-

1 Robertson and Burnett, Jour. Exp. Med., Vol. 17, No. 3, I913, p. 344; Proc. Soc. Exp. BIol. AND MED., Vol. ro, I913, p. I40. 